\title{
Discovery of Vespa binghami (Vespidae: Hymenoptera) in Korea
}

\author{
Jeong-Kyu Kim ${ }^{1, *}$, Il-Kwon Kim² \\ ${ }^{1}$ Department of Biological Sciences, Faculty of Science, Hanseo University, Seosan 336-706, Korea \\ ${ }^{2}$ Division of Forest Biodiversity, Korea National Arboretum, Pocheon 487-821, Korea
}

\begin{abstract}
Vespa binghami Vecht, a poorly known vespine species, was discovered in Korea. This is the second treatment of this species on the Korean peninsula since the first report on Korean occurrence by Virula in 1925; however, the first one was based on practical Korean distributional information. Diagnostic description and digital images are provided.
\end{abstract}

Keywords: Vespa binghami, Korea

\section{INTRODUCTION}

Korean occurrence of Vespa binghami was first reported by Birula (1925) as a new species of Vespa sprunenkoi. His original description was based on a holotype from Sackhalin (Russia) and two paratypes from Korea. However, he did not give any Korean locality. Later taxonomic works on South Korean Vespa species, such as those by Kim et al. (1994) and Kim et al. (2006), also did not deal with this species; therefore, the Korean locality of the species has remained undiscovered.

We recently discovered specimens of this distinct species deposited at the Korea National Arboretum (KNA). This species is known to be nocturnal or crepuscular (van der Vecht, 1959), and very easily distinguished from other Vespa species by a large ocelli and short oculus-ocellus distance.

This is the second Korean record concerning this species; however, the first report included domestic distributional data. Diagnostic description and digital images of this species are presented.

\section{SYSTEMATIC ACCOUNTS}

Order Hymenoptera Linnaeus, 1758

Family Vespidae Latreille, 1902

Genus Vespa Linnaeus, 1758
${ }^{1}$ *Vespa binghami du Buysson, 1905

Vespa binghami du Buysson, 1905: 488 (in key), 523, 우, "Tennaserim, Taungoo Hills", Myanmar, (lectotype in Paris Mus.); van der Vecht, 1959: 216 (lectotype designation); Archer, 1989: 10 (in key), 33; Kurzenko, 1995: 283284 (in key); Carpenter and Kojima, 1997: 67 (listed).

Vespa sprunenkoi Birula, 1925: 89 (in key), 92, 우, "Insel Sachalin", Russia, also from Korea (St. Petersburg); Archer, 1989: 33 (synonymize with V. binghami).

Female (queens and workers). Body 21.0-31.5 mm long, and forewing 19.0-25.6 mm long (Fig. 1A, B). Ocellus large, its diameter almost as long as the basal breadth of antennal flagellum I; oculus-ocellus distance (shortest distance between inner margin of compound eye and outer margin of posterior ocellus) very short, less than two-thirds of anterior ocellus diameter (Fig. 1F). Gena somewhat strongly extended outwardly, its margin visible in frontal view (Fig. 1E); in profile, the ratio of gena width to eye one approximately 1.4 in the broadest portion. Clypeus somewhat strongly swollen, with coarse large dense punctures in its apical half and smaller finer ones in its basal half; its apical margin emarginate (emargination broadly rounded, but much less than semicircular); tips of apical teeth rounded, almost semicircular in shape (Fig. 1E). Pretegula carina complete.

Following parts/markings deep yellow or orange yellow, often partially tinged with ferruginous yellow (Fig. 1A, B). Almost entire face of head including frons, vertex, gena,

\footnotetext{
*To whom correspondence should be addressed

Tel: 82-41-660-1349, Fax: 82-41-688-3403

E-mail: kwasp@hanseo.ac.kr
}

Commons Attribution Non-Commercial License (http://creativecommons org licenses/by-nc/3.0/) which permits unrestricted non-commercial use, distribution, and reproduction in any medium, provided the original work is properly cited.

Korean name: ${ }^{1 *}$ 큰홑눈말벌 


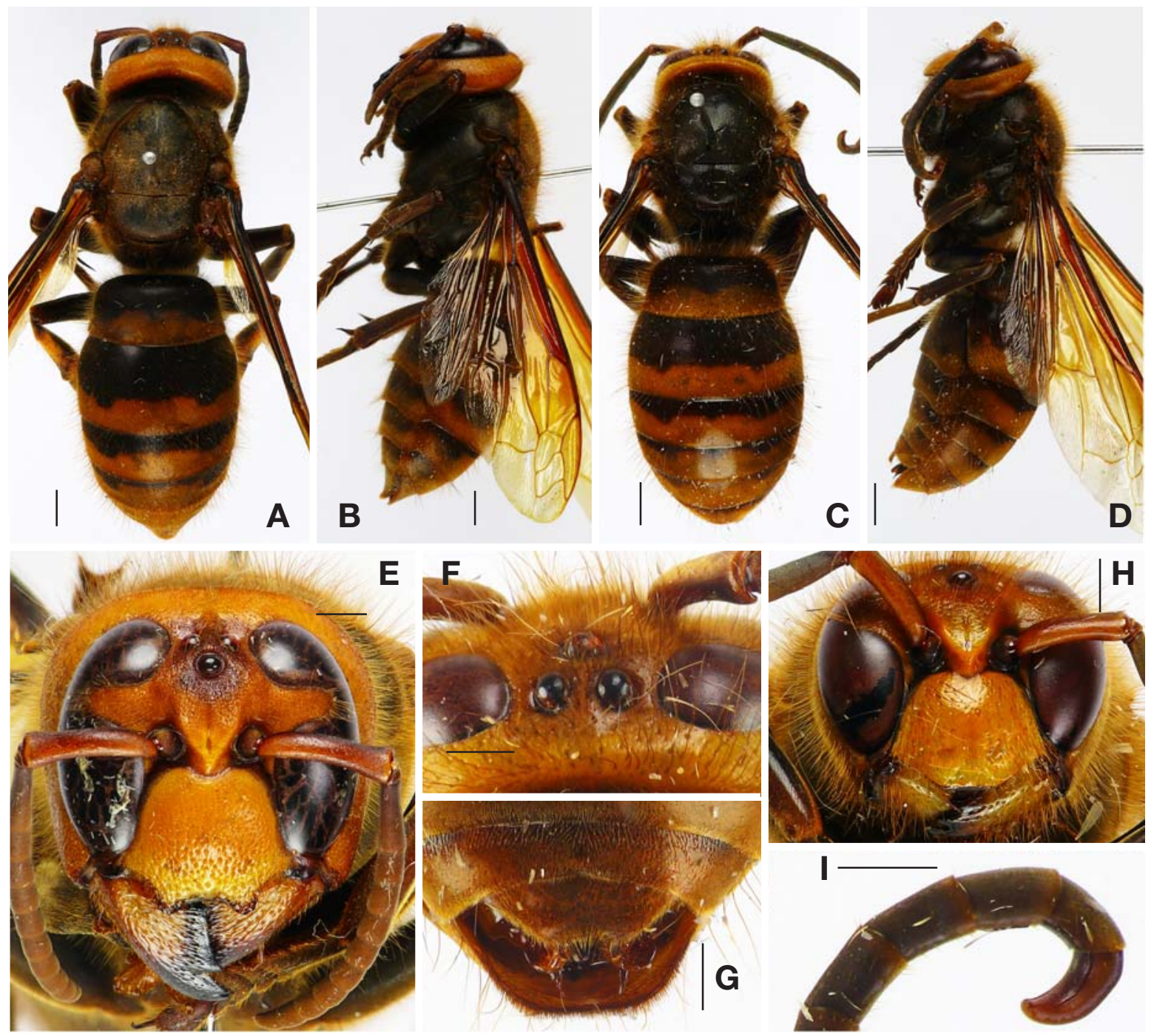

Fig. 1. Vespa binghami du Buysson. A, General habitus, dorsal, 우; $B$, General habitus, in profile, 우; C, General habitus, dorsal, 중 D, General habitus, in profile, $0^{x}$; E, Head, in full frontal view, 우; F, Ocellar region, 우; G, Metasomal sterna VI-VII, o $0^{x}$; H, Head, in full frontal view, $0^{7}$; I, Last five antennal segments, $\sigma^{7}$. Scale bars: $A-D=2 \mathrm{~mm}, E-I=1 \mathrm{~mm}$.

clypeus, larger part of mandible except for near apical teeth area. Thick apical bands on metasomal terga I-V: anterior margins of bands sinuous, bands on terga I-II almost in apical half, and bands on terga III-V in almost entire exposed faces. Apical band of sterna II-V. Entire face of metasomal segment VI. Following parts/markings bright ferruginous or reddish: tibiae of all legs, ocellar region, antennae, pronotal tubercle, anterior and posterior margins of pronotal dorsum, posterior margin of scutellum, and disks of terga III except for apical bands area.

Entire body being covered with yellowish (partially somewhat deep yellowish or brownish) dense erect hairs, without blackish ones.

Male (based on one specimen). Body $25.5 \mathrm{~mm}$ long, and forewing $21.1 \mathrm{~mm}$ long (Fig. 1C, D). Ocelli large as in female, but oculus-ocellus distance longer than one in female, but still shorter than ocellus diameter. Head, in frontal view, much broader than long (Fig. 1H). Gena not strongly extended outwardly as in female, its margin not visible in upper half $($ Fig. $1 \mathrm{H})$; the ratio of gena width to eye one approximately 1.3. Clypeus broader than high (approximately 1.3 as broad as long) and somewhat polished with fine sparse punctures, especially its median part almost impunctate; clypeal apical margin truncate (Fig. 1H). Lower face of antennal segments XI-XIII with tyloids (one on segment XI linear in shape, and ones on segment XII-XIII covering almost entire lower faces); last segment tapering and bent backward, longer than penultimate segment (Fig. 1I). Apicomedian 
margin of sternum VI slightly notched; larger median part of sternum VII depressed, and its apical margin broadly rounded including apicomarginal lamellate plate (Fig. 1G). Coloration and hair condition much as in female.

Specimens examined. Korea: Gyeonggi-do: 2 우 우, Gwangneung, 13 Oct 1988, Weon GJ (KNAE0301212002, KNAE 0303262001); 1 우, ditto, 4 Oct 1997, Weon GJ (KNAE030 1212001); 1 우, Gwangneung, Korean National Arboretum, $37^{\circ} 44^{\prime} 54.73^{\prime \prime} \mathrm{N}, 127^{\circ} 04^{\prime} 50.09^{\prime \prime} \mathrm{E}, 17$ Aug 2006, Han HJ (KNAE65355); 3 우 우, Gwangneung, Lake Yuklim, $37^{\circ}$ $44^{\prime} 54.95^{\prime \prime} \mathrm{N}, 127^{\circ} 90^{\prime} 49.23^{\prime \prime} \mathrm{E}, 1$ Jun 2010, Park SY, Koh KH, Yii KA (KNAE241039, KNAE241094, KNAE241096); 1 우, ditto, 1 Jul 2010, Park SY, Lim JS (KNAE241095); 2 우 우, ditto, 29 Jul 2010, Park SY, Lim JS, Ko KH, Kim KM (KNAE241884, KANE241885); 2 우 우, ditto, 19 Aug 2010, Park SY, Lim JS, Ko KH, Kim KM (KNAE274135, KANE 274136); 1 우, ditto, 6 Sep 2010, Park SY, Lim JS, Ko KH, Kim KM; Gangwon-do: 1 우, Inje-gun, Nam-myeon, Mt. Maebongsan, $37^{\circ} 57^{\prime} 18.4^{\prime \prime} \mathrm{N}, 127^{\circ} 59^{\prime} 55.8^{\prime \prime} \mathrm{E}, 20$ Jul 2010, Park SY, Lim JS, Kim KM; Gyeonggi-do: $10^{7}$, 1 우, Gwangneung, Korean National Arboretum, $33^{\circ} 24^{\prime} 08.54^{\prime \prime} \mathrm{N}, 126^{\circ}$ 22'53.18'E, 12 Oct 2010, Park SY, Lim JS.

Distribution. India, Bhutan, Myanmar, Thailand, Laos, Vietnam, China, Far Eastern Russia, Korea.

\section{ACKNOWLEDGEMENTS}

This work was supported by the Survey of Indigenous Biological Resources of Korea Project, NIBR, and the Ecotechnopia 21 Project.

\section{REFERENCES}

Archer ME, 1989. A key to the world species of the Vespinae (Hymenoptera) Part I Keys, checklist and distribution. Academic Board Research Committee of the College of Ripon \& York St. John, York, pp. 1-44.

Birula A, 1925. Über die russischen Wespen und ihre geographische Vesbreitung. Archiv für Naturgeschichte, 90:88102.

Carpenter JM, Kojima J, 1997. Checklist of the species in the subfamily Vespinae (Insecta: Hymenoptera: Vespidae). Natural History Bulletin of Ibaraki University, 1:51-92.

du Buysson R, 1905. Monographie des Guêpes ou Vespa. Annales de la Société Entomologique de France, 73:485-556.

Kim JK, Choi M, Moon TY, 2006. Occurrence of Vespa velutina Lepeltier from Korea, and a revised key for Korean Vespa species (Hymenoptera: Vespidae). Entomological Research, 36:112-115.

Kim JK, Moon TY, Yoon IB, 1994. Systematics of Vespine wasps from Korea, 1. Genus Vespa Linnaeus (Vespidae, Hymenoptera). Korean Journal of Entomology, 24:107-115.

Kurzenko NV, 1995. Family Vespidae. In: Key to the insect of Russian Far East. Vol. VI. Neuroptera, Mecoptera, Hymenoptera. Part 1 (Ed., Lehr PR). Nauka, St. Petersberg, pp. 264-324.

van der Vecht J, 1959. Notes on Oriental Vespinae, including some species from China and Japan (Hymenoptera, Vespidae). Zoologische Mededelingen, 36:205-232. 